\title{
In Vitro Assessment of the Toxic Effects of an AKWATON based-disinfectant on Human Tissues
}

Mathias K Oulé*, Christine Lesage, Julie Gauvin, Mona Friesen, Michael Dickman, Anne-Marie Bernier and Lamine Diop

Department of Experimental Science, Faculty of Science, Université de Saint-Boniface, Canada

*Corresponding author: Mathias K Oulé, Department of Experimental Science, Faculty of Science, Université de Saint-Boniface, 200, de la Cathédrale Avenue, Winnipeg, MB, R2H 0H7, Canada, Tel: 2042371818 (Extn: 499); E-mail: moule@ustboniface.ca

Received date: April 11, 2017; Accepted date: April 26, 2017; Published date: May 04, 2017

Copyright: ( 2017 Oulé MK, et al. This is an open-access article distributed under the terms of the Creative Commons Attribution License, which permits unrestricted use, distribution, and reproduction in any medium, provided the original author and source are credited.

\begin{abstract}
The purpose of this study is to prove the potential safe use of AKWATON as a new antimicrobial product. Many service products are often removed from the market due to their toxic effects on the human body or to their aggressiveness towards the environment. Antimicrobial products such as disinfectants may contain harmful ingredients that can cause disease. Some disinfecting products are corrosive or irritating; others produce strong odors, which in the long run can cause real health problems. AKWATON is a new disinfectant, member of the family of guanidine polymers.

Its bactericidal, fungicidal and sporicidal properties have been demonstrated and widely documented. In this study, the toxic effects of AKWATON and of three well known commercial antimicrobial products currently on market, were evaluated and compared on various human tissues including eyes, lung, skin and liver cells. The testing were performed using the TB (Trypan blue) and MTT (3-(4,5-Dimethylthiazol-2-yl)-2, 5-diphenyltetrazolium bromide) methods. Cell-cultures and the different tests done, showed that the AKWATON based-disinfectant was much less toxic, killing many fewer cells than the commercial disinfectants. It spared more than $64 \%$ of skin cells; $65 \%$ of lung cells; $66 \%$ of eye cells and $64 \%$ of liver cells while some well-known disinfectants currently marketed killed $100 \%$ of cells. This study demonstrated that AKWATON can be used as an odorless, colorless, non-corrosive and harmless disinfectant for hospital, agriculture industry, farming, food service and household facilities or as antiseptic.
\end{abstract}

Keywords: AKWATON; Toxic effects; Disinfectants; Antiseptics; Lung cells; Skin cells; Eye cells; Liver cells

\section{Introduction}

Disinfection ensures the partial or total removal of microorganisms on soiled objects (instruments, clothing, surfaces, etc.) while any chemical treatment applied to living tissue in order to destroy or eliminate potentially pathogenic microorganisms, or slow their growth, is called antisepsis. Chemicals used to clean objects and surfaces in contact with microorganisms are called disinfectants and those applied to living tissues are called antiseptics [1]. The history of the use of chemicals to fight micro-organisms goes back to the time of ancient Egypt [2]. In the $19^{\text {th }}$ century, disinfection and antisepsis changed with the discovery of chemicals such as chlorine by Carl Scheele; iodine by Bernard Courtois and hydrogen peroxide by Louis Thénard [3]. Today disinfection and antisepsis are daily acts applied in a multitude of environments (households, industries, hospitals, public places, etc.). Antimicrobial chemicals are used every day by millions of people around the world. Unfortunately, they do not have selective action and affect both microorganisms and mammalian cells [4]. Disinfectants and antiseptics contain active molecules that, not only, inhibit the growth of microorganisms or kill them, but also produce toxic effects on human and animal cells $[5,6]$. On the other hand, active ingredients in some antimicrobial products induce resistance, even to antibiotics in bacteria [1]. This is the case of triclosan [7,8]. For this reason, governments increasingly remove certain service products from the market. Recently in USA, The FDA (Food and Drug Administration) banned the use of triclosan, triclocarban and 17 other chemicals in disinfectants for hands and in liquid soaps $[9,10]$. Furthermore like triclosan, many other chemical ingredients are associated with allergies [11,12]. To avoid the toxic effects of the chemicals we use every day, and to preserve the environment, it is therefore necessary to explore other molecules capable of killing microorganisms without affecting human and animal organisms.

Antimicrobial biocides have long been in use in domestic and clinical environments. For over half a century, cationic biocides have been prominent among other agents used to combat cross-infections and have contributed to the overall reduction in nosocomial infections [13]. Correct application of these biocides plays a very effective role in the elimination of infection in veterinary, dental, domestic and hospital settings [1]. Polyhexamethylene biguanide (PHMB), a member of the polymeric guanidine family, has broad-spectrum activity against Gram-positive and Gram-negative bacteria, fungi, yeasts [14] and viruses, including human immunodeficiency virus [15]. It has been widely used for many years as an antiseptic in medicine and the food industry, as a mouthwash [16], as a disinfectant for a variety of solid surfaces [17] and also in water treatment [18]. AKWATON is a polyhexamethylene guanidine hydrochloride (PHMGH) based formulation of a novel disinfectant. PHMGH, a member of the guanidine family, is a polymer with bactericidal, fungicidal, and sporicidal, properties that has been demonstrated to work at low concentrations with short contact times [19-21]. The bactericidal activity against E. coli and meticillin-resistant Staphylococcus aureus (MRSA) and the mode of action of PHMGH have been clearly demonstrated by Oulé et al. [20]. Their results showed that no matter what type of water (distilled, tap and hard water) was used to make 
dilutions, AKWATON killed MRSA and E. coli respectively at a low concentration of $0.04 \%$ and $0.005 \%$ within 1.5 minutes [19]. These authors also demonstrated that the minimum sporostatic concentration, the minimum sporicidal concentration and the time required for sporicidal activity corresponded to $0.06 \%(\mathrm{w} / \mathrm{v}), 0.08 \%$ $(\mathrm{w} / \mathrm{v})$ and 8.5 minutes, respectively [19]; and that the minimum inhibitory concentration, the minimum fungicidal concentration (MFC) and time required for the fungicidal activity of AKWATON at the MFC were $0.025 \%(\mathrm{w} / \mathrm{v}), 0.045 \%(\mathrm{w} / \mathrm{v})$ and $2.5 \mathrm{~min}$, respectively Oulé et al. [20].

Other previous studies have demonstrated that PHMGH, the active ingredient of the new AKWATON-based disinfectant, is an odourless, colourless and noncorrosive polymer with high solubility in water [22] and is significantly less toxic and harmless than currently used disinfectants $[14,23]$ to humans and animals at a concentration $\leq 1 \%$. In addition, cell cultures and the different tests carried out by Oulé et al. [20], showed that the new AKWATON-based disinfectant killed fewer animal cells than the commercial disinfectants, sparing $80 \%$ of rat pancreatic (C2C12) cells and $65 \%$ of muscle RnM5F cells, whilst some of the well-known disinfectants currently on the market killed $85-100 \%$ of those cells.

To demonstrate its potential use as a less hazardous antibacterial than the currently used disinfectants, and to validate its use as an antiseptic and an ideal disinfectant for households and hospitals, the toxic effects of AKWATION have been assessed on human tissues.

\section{Material and Methods}

Human cells used in this study were lung cells (IMR-90 (ATCC

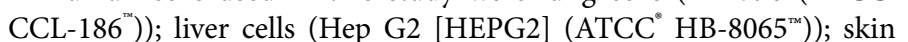
cells (A-431 (ATCC ${ }^{\circ}$ CRL-1555"')) and eye cells (ARPE-19 (ATCC ${ }^{\circ}$ CRL-2302 $\left.2^{\text {tw}}\right)$ ), purchased from American Type Culture Collection (ATCC) ((Manassas, Va., USA). All the reagents have been purchased from Sigma Chemical Co. (St Louis, MO, USA). Cells were maintained at $37^{\circ} \mathrm{C}$ under a continuous $5 \% \mathrm{CO}_{2}$ atmosphere.

\section{Assessment of the effect of disinfectants on cells}

AKWATON (0.05\%) and three well-known and currently marketed antimicrobial chemicals including Ethanol (70\%), DEXIDIN-4, and the commercial disinfectant LYS purchased from Canadian Real Super Store (Winnipeg, MB, Canada) were used to treat the four types of human cells. Skin cell (A-431 (ATCC ${ }^{\circ}$ CRL-1555")) cells and eye cells (ARPE-19 (ATCC ${ }^{\circ}$ CRL-2302 ${ }^{\circ}$ )) were plated at 7,500 cells $/ \mathrm{cm}^{2}$ and cultured in DMEM (Dulbecco's Modified Eagle's Medium); and Lung cells (IMR-90 (ATCC CCL-186 ${ }^{\circ}$ )) and liver cells (Hep G2 [HEPG2] $\left(\right.$ ATCC $^{\circ}$ HB-8065 $\left.5^{\prime \prime \prime}\right)$ ) in EMEM (Eagle's Minimum Essential Medium).

All media were supplemented with $1 \%$ Penicillin, $1 \%$ Streptomycin, $2 \mathrm{mM}$ glutamine and $10 \%$ fetal bovine serum (FBS). Cells were incubated at $37^{\circ} \mathrm{C}$ under a continuous $5 \% \mathrm{CO}_{2}$ atmosphere for 24 hour to $65-75 \%$ confluency. Before each test, cells were detached using $0.05 \%$ trypsin. Cells were exposed to AKWATON-based disinfectant and to three other well-known commercial antimicrobial chemicals for 10 minutes.

Cultures with $\geq 95 \%$ viable cells were used for experiments. The viability of cells before and after treatment was tested by trypan blue exclusion tests and MTT test. Cells were observed under a microscope and counted using a hemocytometer. Calculation: Cell
Viability $(\%)=$ total viable cells (unstained) $\div$ total cells (stained and unstained) $\times 100[24]$.

\section{Statistical analysis}

Three different batches of the AKWATON-based disinfectant and four three well-known commercial antimicrobial chemicals were used to treat the four types of cells. For AKWATON, reported data was the average of the results from the three batches tested. Each test with each chemical was performed in duplicate and repeated three times. Results were analyzed using one-way analysis of variance and Student's t-test. Differences with a value of $\mathrm{P}<0.05$ were considered statistically significant.

\section{Discussion}

The purpose of applying disinfectants and antiseptics is to kill microorganisms or prevent their development. But an equally important thing is to ensure that the application of these antimicrobial products does not affect the human and animal health and does not affect the environment, which is a real concern with the majority of commercial chemicals currently on the market. The advent of new bacterial strains that are increasingly resistant to antibiotics and disinfectants is a serious problem that deserves more attention and to which a durable solution must be found.

This is why it is necessary to develop new molecules with powerful antimicrobial properties, but harmless for human and animal organisms and for the environment. AKWATON is a new colorless, odorless, non-corrosive antimicrobial product with excellent microbicidal power. Its antimicrobial activities have been widely documented [19,25-27].

Oulé et al. [19] have clearly demonstrated its bactericidal activity against Staphylococcus aureus, Pseudomonas aeruginosa, Salmonella choleraesuis, meticillin-resistant $S$. aureus (MRSA) and E. coli; its sporicidal activity against Bacillus subtilis spores [20] and its fungicidal activity against Trichophyton mentagrophytes [4]. In addition to its microbicidal properties, it has been demonstrated that AKWATON was much less toxic to rat cells than well-known disinfectants currently on the market. Oule et al. [4] established that the AKWATON-based disinfectant was much less toxic to rat pancreatic and muscle cells.

The AKWATON-based disinfectant killed fewer cells than the commercial disinfectants, sparing $80 \%$ of C2C12 (ATCC ${ }^{\circ}$ CRL-1772 ${ }^{\prime \prime \prime}$ ) cells and $65 \%$ of RIN-m5F (ATCC CRL-11605 ${ }^{\circ}$ ) cells, whilst LYS and MCL, currently on the market, killed $85 \%-100 \%$. The purpose of this in vitro study is to show that AKWATON is also less toxic to human cells than commercial antimicrobial products. The in vitro tests with cell lines are a good alternative to the use of laboratory animals in toxicological studies. Animal protection organizations are increasingly opposed to laboratory experiments on animals, because of the cruelty inherent in these practices [28].

In this study, the toxic effects of AKWATON (0.05\%) (a novel antimicrobial product), Ethanol (70\%), DEXIDIN-4 (a commercial antiseptic) and LYS (a commercial disinfectant) were assessed on human cells including eyes, skin, lung and liver cells in In-vitro experiments. Figure 1 shows untreated cells which, have served as a control to observe and evaluate the effects of the four antimicrobial products tested. Untreated cells were numerous, healthy and evenly distributed in the visual field of the microscope. 


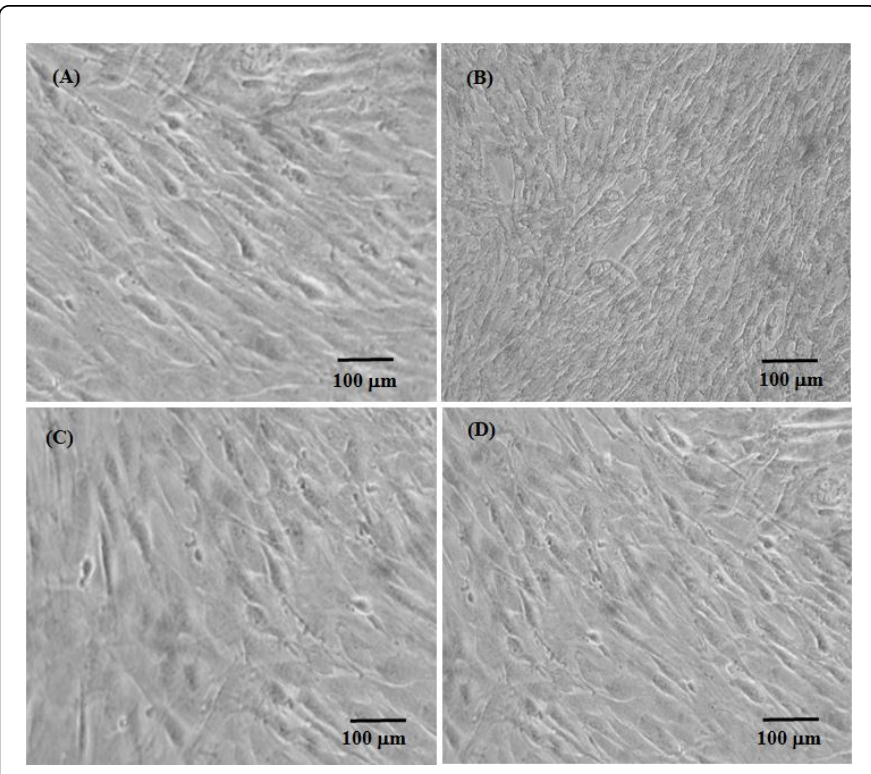

Figure 1: Control, untreated cells; (A): Skin cells; (B): Lung cells; (C): Eyes cells and (D): Liver cells.

The Figure 2 compares the survival of the four types of human cells exposed to various chemicals mentioned above. Each antimicrobial product killed the same percentage of cells in the four cell types. For each antimicrobial product, there was no significant difference between the cell types $(\mathrm{P}>0.05)$. However, for each cell type a significant difference was observed between antimicrobial products $(\mathrm{P}<0.05)$, except between AKWATON $(0.05 \%)$ and Ethanol $(70 \%)$ $(\mathrm{P}>0.05)$. Among the four antimicrobial products, LYS was highly toxic, killing $100 \%$ of each of the four cell types used, probably due to its chemical composition.

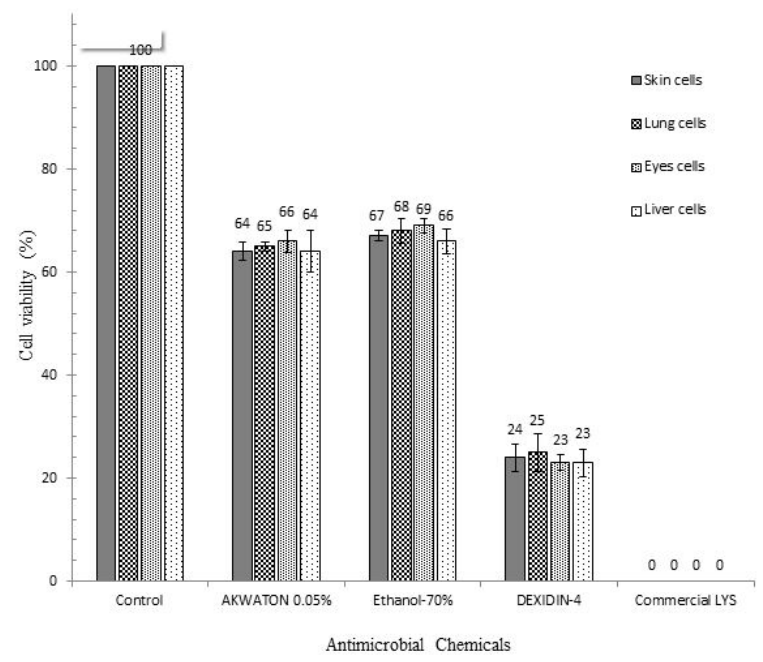

Figure 2: Viability of 4 human cell types (Skin, Lung, Eyes and Liver cells) after treatment with different antimicrobial products. Control cells were untreated.
The commercial disinfectant LYS used in this study is a mixture of several active ingredients such as Ethyl alcohol, Butane, Propane and N-Alkyl-dimethyl benzyl ammonium chloride. The morphology of cells after their exposure to LYS suggests that the disinfectant attacked various targets on cells. Their appearance suggests that some active molecules in the disinfectant LYS fragmented the plasma membrane followed by penetration of other actives molecules into the cells that attack cytoplasmic components, causing loss of the cytoplasm, total collapse of the cells and resulting in an appearance of puree of the cell mass. Figure 3 shows cells after a 10 min-treatment with LYS. All cells were completely destroyed.

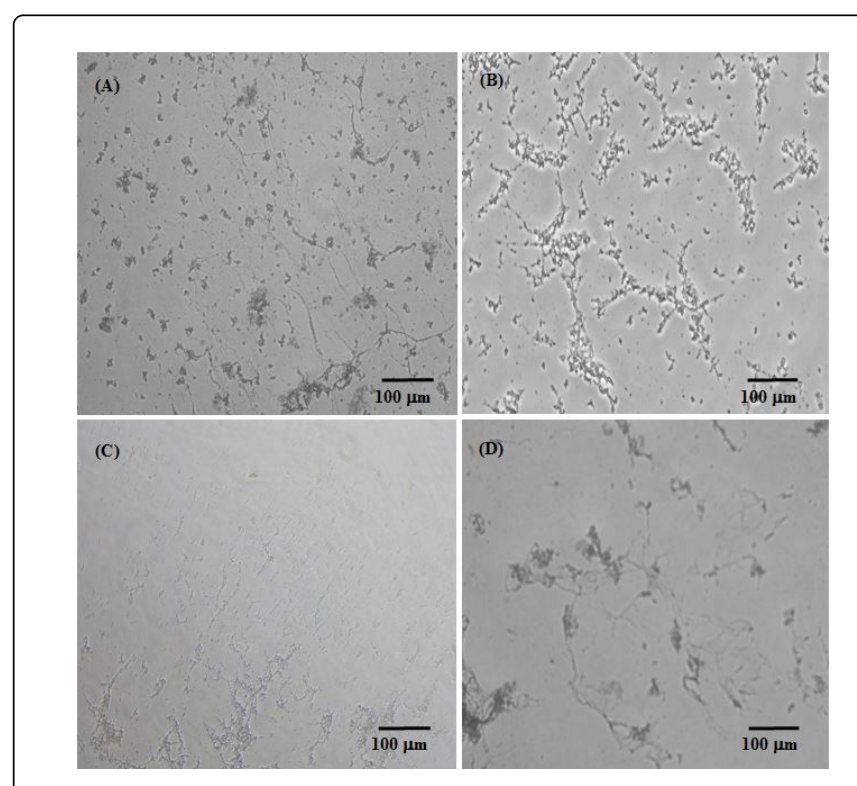

Figure 3: Effects of the commercial disinfectant LYS on human cells; (A): Skin cells; (B): Lung cells; (C): Eyes cells and (D): Liver cells.

DEXIDIN-4 also caused a high percentage of cell death killing approximately $75 \%$ of cells in each cell type. Figure 4 shows cells after their treatment with DEXIDIN-4. DEXIDIN-4 was toxic to cells but less than LYS. There was a significant difference between DEXIDIN-4 and LYS $(\mathrm{P}<0.05)$. DEXIDIN-4 is used as an antimicrobial surgical cleaner; antiseptic cleaner for skin and minor injuries and for hand washing in hospitals, labs and food services. DEXIDIN-4 is composed of $4 \%$ chlorhexidine gluconate and $4 \%$ isopropyl alcohol. Depending on the concentration, each of these two chemical compounds can be toxic to mammalian cells, and their modes of action on cells are very well documented. Isopropanol is an active ingredient that can cause cell death at relatively low concentrations such as $4 \%$ in the antiseptic DEXIDIN-4. Kasajima, et al. [29] reported in an in vitro study that the inhibition of DNA, RNA and protein-syntheses of the mammalian cells was induced by treatment with ethyl alcohol at $1 \%$ to $10 \%(\mathrm{~V} / \mathrm{V})$ for 2 hours, in a dose-related manner. In DEXIDIN-4, the other main active ingredient is $4 \%$ chlorhexidine gluconate. An in vitro study by Flemingson et al. [30], comparing the effects of three mouth rinses on human gingival fibroblasts, showed that these three rinses were toxic to the cells, chlorhexidine being the most cytotoxic. Taner et al. [31] have also demonstrated the genotoxic and cytotoxic effects of chlorhexidine on human lymphocytes. According to Nancy and Don [32], cultured human periodontal cells treated with $2 \%$ chlorhexidine exhibited a foamy appearance in which most of the cytoplasm seemed to have been extracted from the cells. According to an in vivo genotoxicity 
Citation: Oulé MK, Lesage C, Gauvin J, Friesen M, Dickman M, et al. (2017) In Vitro Assessment of the Toxic Effects of an AKWATON based-

study conducted by Grassi et al. [33] in rats, chlorhexidine induced DNA damage in leukocytes, renal cells and oral mucosal cells. And in an in vitro study on rat oral mucosal cells and rat leukocytes, Ribeiro et al. [34] demonstrated that Chlorhexidine was highly cytotoxic, inducing oxidative stress and apoptotic and necrotic cell death. In this study, the treatment with DEXIDIN-4 resulted in the death of approximately $75 \%$ of cells of each cell type. Such high rate of cell death results directly from the elevated toxicity of DEXIDIN-4 on the cells. This high toxicity could be attributed to the combined actions of alcohol and chlorhexidine on the cells.
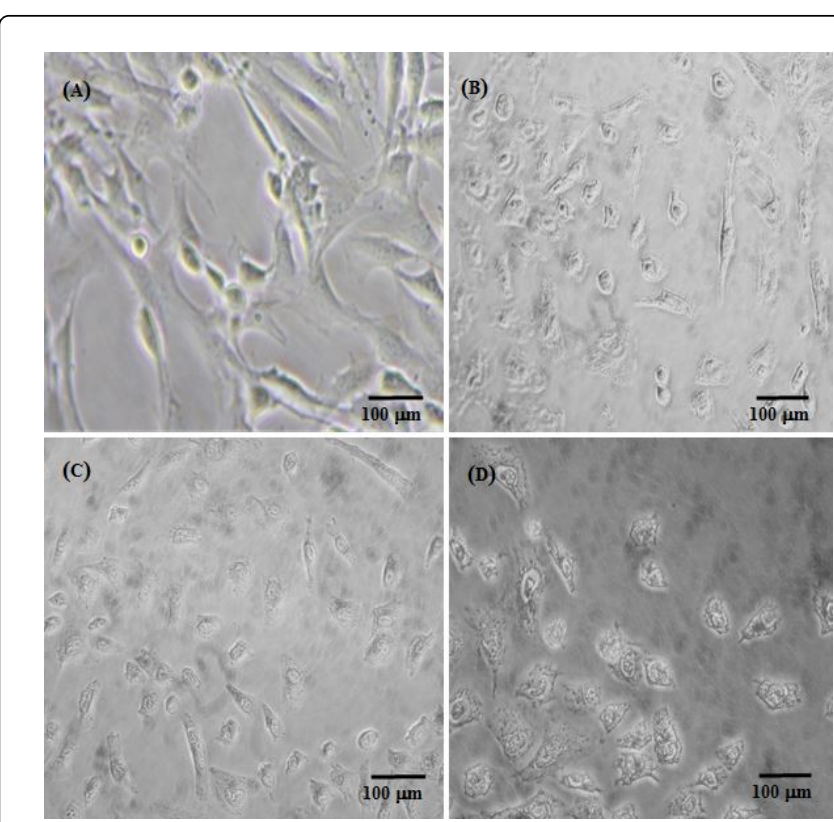

Figure 4: Effects of Dexidin-4 on human cells; (A): Skin cells; (B): Lung cells; (C): Eyes cells and (D): Liver cells.

The other two antimicrobial products, AKWATON (0.05\%) and Ethanol (70\%) produced less cytotoxic effects on each cell type. When the cells were exposed to AKWATON (0.05\%), respectively 64\%, 65\%, $66 \%$ and $64 \%$ of the skin, lung, eye and liver cells survived (Figure 1). Similar results were observed with Ethanol (70\%). There was no significant difference between their effects on the cells $(\mathrm{P}>0.05)$. These two chemicals (Ethanol and AKWATON) killed about 30\% to $35 \%$ of cells. Figures 5 and 6 show the appearance of the four cell types after their treatment with AKWATON-0.05\% and Ethanol (70\%).

In an in vitro study, Lingna et al. [35] examined the effects of Ethanol on mouse skin cells and they observed a dose-dependent toxic effect. When the concentration reached $50 \%$, more than $75 \%$ of cells were killed after 2 days of exposure. In this study, we observed about $30 \%$ of cell death, probably because of the short exposure time of 10 min. The cells that survived treatment with AKWATON-0.05\% (Figure 5) or with Ethanol (70\%) (Figure 6) seemed to be healthy compared to untreated cells (Figure 2). The effect of Ethanol is known; it acts on the biological membrane by interdigitating the two lipid layers, thus reducing its thickness and increasing its permeability [36]. Oulé et al. [19] suggested that the main target of PHMGH, the active molecule in AKWATON, seems to be the cell envelope. PHMGH would penetrate the cell envelope, attacking the bacterial cell wall and the membrane at the same time.

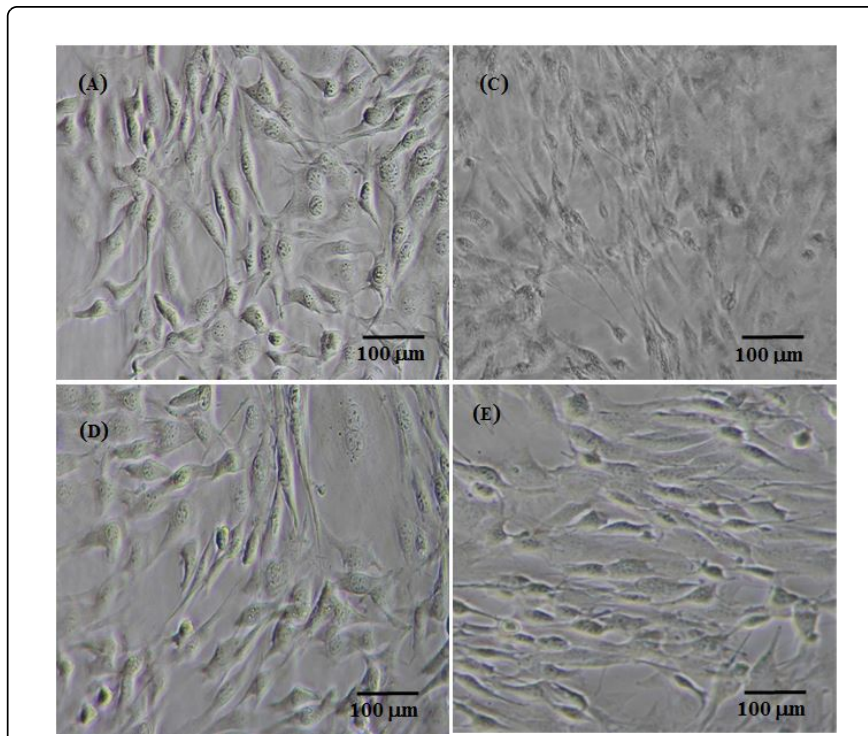

Figure 5: Effects of AKWATON (0.05\%) on human cells; (A): Skin cells; (B): Lung cells; (C): Eyes cells and (D): Liver cells.

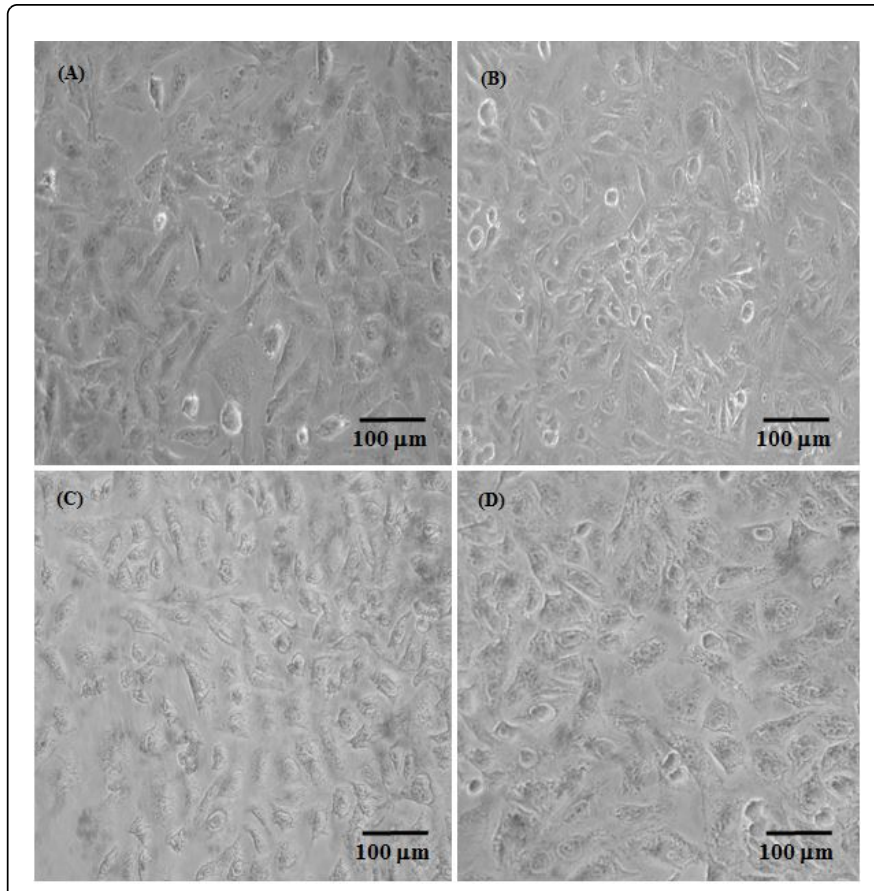

Figure 6: Effects of Ethanol-70\% on human cells; (A): Skin cells; (B): Lung cells; (C): Eyes cells and (D): Liver cells.

The relative resistance of animal and human cells to AKWATON and Ethanol could be explained by the composition and structure of their membrane. For example, the presence of cholesterol and the quality of membrane lipids (length, saturation and level of branching) would enhance the integrity and the stability of the membrane of animal and human cells. Cholesterol is a major component of mammalian cell membranes. It contributes to the stability and the maintenance of membrane structure by intercalating between the 
phospholipids, acting as a pillar of resistance to attacks on the membrane. Essentially, cholesterol intervenes in the integrity, the stability and the maintenance of membrane fluidity [37]. Cholesterol also contributes to the tightness of cell membranes, reducing their permeability to various substances $[38,39]$. The presence of cholesterol would reduce the penetration of PHMGH and Ethanol into cells, which would mitigate their toxicity on cells.

One wonders why the presence of cholesterol in the cell membrane could not allow the cells to resist to LYS or DEXIDIN-4. In fact, the chemical composition of LYS and DEXIDIN-4 is complex. These two antimicrobial products contain more than one active ingredient. LYS and DEXIDIN-4 are mixtures of several active components and were found to be highly toxic to the four cell types (Figure 1). The presence of several active molecules in an antimicrobial product can be effective in eliminating or reducing the spread of potentially pathogenic microorganisms, but can also generate toxic effects on mammalian cells. In AKWATON there is only one active molecule, the PHMGH, which acts on cell membranes [19]. In this study, AKWATON was shown to be much less toxic to human cells. In a previous study, Oule et al. [4] showed that AKWATON (0.05\%) was much less toxic to rat cells than commercial disinfectants. In another study, the same authors showed that AKWATON (0.04\%) was very toxic for bacterial cells [19]. It is known that the membrane of the bacterial cell does not contain cholesterol. The presence of cholesterol would seem to be a determining factor for the effect of AKWATON.

\section{Conclusion}

The growing resistance of pathogenic microorganisms to antibiotics and antimicrobial chemicals, as well as the toxicity of these products to human and animal organisms and their aggressiveness to the environment, are real concerns. AKWATON, an odourless, colourless, stainless and non-corrosive substance with high bactericidal, fungicidal and sporicidal potency, is significantly less toxic to human lung, liver, skin and eye cells than two commercial antimicrobial products currently on the market. Compared to some commercial chemicals that kill $100 \%$ human cells in vitro, AKWATON produces the same effects as $70 \%$ ethanol, widely known and used all over the world, killing only $30 \%$ of human cells. This study demonstrates that AKWATON with all of these properties is an ideal antimicrobial product for hospitals, laboratories, food industries and household facilities.

\section{Acknowledgement}

The authors are grateful to the Research and Development Committee of Université de Saint-Boniface for financial support, to FOSFATON-AKWATON INTERNATIONAL Ltd for providing AKWATON, and also to the reviewers for their guidance and helpful comments on the manuscript.

\section{References}

1. McDonnell G, Russell AD (1999) Antiseptics and disinfectants: Activity, action, and resistance. Clin Microbiol Rev 12: 147-179.

2. Dunker MFW (1938) A history of early antiseptics. J Chem Educ 15 (2): 58-59.

3. Dauphin A, Mazin C (1944) Les antiseptiques et les désinfectants. (1st edn) Arnette, Paris.
4. Oulé MK, Staines K, Lightly T, Roberts L, Traoré YL, et al. (2015) Fungicidal activity of AKWATON and in vitro assessment of its toxic effects on animal cells. J Med Microbiol 64: 59-66.

5. McCauley RL, Linares HA, Pelligrini V, Herndon DN, Robson MC, et al. (1989) In vitro toxicity of topical antimicrobial agents to human fibroblasts. J Surg Research 46: 267-274.

6. Lineaweaver W, Howard R, Soucy D, McMorris S, Freeman J, et al. (1985) Topical antimicrobial toxicity. Arch Surg 120: 267-270.

7. Rungtip C, Kerry B, Tung TH, Anna B, Roxann RK, et al. (2001) Crossresistance between triclosan and antibiotics in Pseudomonas aeruginosa is mediated by multidrug efflux pumps: Exposure of a susceptible mutant strain to triclosan selects nfxb mutants overexpressing MexCD-OprJ. Antimicrob Agents Chemother 45: 428-432.

8. Siamak PY, Anne AS, Arne EH, Bjørn-Tore L, Even H, et al. (2006) Triclosan and antimicrobial resistance in bacteria: An overview. Microb Drug Resist 12: 83-90.

9. U.S. Food and Drug Administration (2016) FDA issues final rule on safety and effectiveness of antibacterial soaps. FDA News Release.

10. Tavernise S (2016) F.D.A. bans sale of many antibacterial soaps, saying risks outweigh benefits. The New York Times.

11. Sicherer SH, Leung DY (2013) Advances in allergic skin disease, anaphylaxis, and hypersensitivity reactions to foods, drugs, and insects. J Allerg Clin Immunol 131: 55-66.

12. William J R (1988) Chemical hypersensitivity and the allergic response. Ear Nose Throat J 67: 50-56.

13. Gilbert P, Moore LE (2005) Cationic antiseptics: Diversity of action under a common epithet. J Appl Microbiol 99: 703-715.

14. Müller G, Kramer A (2005) Effect of selected wound antiseptics on adult articular cartilage (bovine sesamoid bone) in the presence of Escherichia coli and Staphylococcus aureus. J Orthop Res 23: 127-133.

15. Krebs FC, Miller SR, Ferguson ML, Labib M, Rando RF, et al. (2005) Polybiguanides, particularly polyethylene hexamethylene biguanide, have activity against human immunodeficiency virus type 1 . Biomed Pharmacother 59: 438-445.

16. Rosin M, Welk A, Bernhardt O, Ruhnau M, Pitten FA, et al. (2001) Effect of a polyhexamethylene biguanide mouthrinse on bacterial counts and plaque. J Clin Periodontol 28: 1121-1126.

17. Hiti K, Walochnik J, Haller-Schober EM, Faschinger C, Aspock H (2002) Viability of acanthamoeba after exposure to a multipurpose disinfecting contact lens solution and two hydrogen peroxide systems. Br J Ophthalmol 86: 144-146.

18. Kusnetsov JM, Tulkki AI, Ahonen HE, Martikainen PJ (1997) Efficacy of three prevention strategies against Legionella in cooling water systems. J Appl Microbiol 82: 763-768.

19. Oulé MK, Azinwi R, Bernier AM, Kablan T, Maupertuis AM, et al. (2008) Polyhexamethylene guanidine hydrochloride-based disinfectant: A novel tool to fight methicillin-resistant Staphylococcus aureus and nosocomial infections. J Med Microbiol 57: 1523-1528.

20. Oulé MK, Quinn K, Dickman M, Bernier AM, Rondeau S, et al. (2012) Akwaton, polyhexamethylene-guanidine hydrochloride-based sporicidal disinfectant: A novel tool to fight bacterial spores and nosocomial infections. J Med Microbiol 61: 1421-1427.

21. Koffi NR, Manizan A, Tano K, Yué BY, Koussémon M, et al. (2011) Assessment of the antifungal activities of polyhexamethylene-guanidine hydrochloride (PHMGH)-based disinfectant against fungi isolated from papaya (Carica papaya L.) fruit". Afri J Microbiol Research 5: 4162-4169.

22. Kuznetsov YI (2004) Physicochemical aspects of metal corrosion inhibition in aqueous solutions. Russ Chem Rev 73: 75-87.

23. Buxbaum A, Kratzer C, Graninger W, Georgopoulos A (2006) Antimicrobial and toxicological profile of the new biocide Akacid plus. J Antimicrob Chemother 58: 193-197.

24. Frei $\mathrm{M}(2011)$ Cell viability and proliferation. BioFiles 6: 17-21.

25. Walczak M, Richert A, Burkowska-But A (2014) The effect of polyhexamethylene guanidine hydrochloride (PHMG) derivatives 
Citation: Oulé MK, Lesage C, Gauvin J, Friesen M, Dickman M, et al. (2017) In Vitro Assessment of the Toxic Effects of an AKWATON baseddisinfectant on Human Tissues. J Antimicrob Agents 3: 140. doi:10.4172/2472-1212.1000140

Page 6 of 6

introduced into polylactide (PLA) on the activity of bacterial enzymes. J Ind Microbiol Biotechnol 41: 1719-1724.

26. Zhou Z, Wei D, Lu Y (2015) Polyhexamethylene guanidine hydrochloride shows bactericidal advantages over chlorhexidine digluconate against ESKAPE bacteria. Biotechnol Appl Biochem 62: 268-274

27. Zhou ZX, Wei DF, Guan Y, Zheng AN, Zhong JJ (2010) Damage of Escherichia coli membrane by bactericidal agent polyhexamethylene guanidine hydrochloride: Micrographic evidences. J Appl Microbiol 108: 898-907.

28. Badyal DK, Desai C (2014) Animal use in pharmacology education and research: The changing scenario. Indian J Pharmacol 46: 257-265.

29. Kasajima N, Tsutsui T (1990) Cytotoxicity of ethyl alcohol on cultured mammalian cells. Shigaku 78: 83-88.

30. Flemingson, Emmadi P, Ambalavanan N, Ramakrishnan T, Vijayalakshmi $\mathrm{R}$ (2008) Effect of three commercial mouth rinses on cultured human gingival fibroblast: An in vitro study. Indian J Dent Res 19: 29-35.

31. Arabaci T, Türkez H, Çanakçi CF, Özgöz M (2013) Assessment of cytogenetic and cytotoxic effects of chlorhexidine digluconate on cultured human lymphocytes. Acta Odontologica Scandinavica 71: 1255-1260.

32. Cline NV, Layman DL (1992) The effects of chlorhexidine on the attachment and growth of cultured human periodontal cells. J Periodontology 63: 598-602.
33. Grassi TF, Camargo EA, Salvadori DM, Marques ME, Ribeiro DA (2007) DNA damage in multiple organs after exposure to chlorhexidine in Wistar rats. Int J Hyg Environ Health 210: 163-167.

34. Ribeiro DA, Bazo AP, da Silva Franchi CA, Marques ME, Salvadori DM (2004) Chlorhexidine induces DNA damage in rat peripheral leukocytes and oral mucosal cells. J Periodontal Res 39: 358-361.

35. Li L, Margolis LB, Hoffman RM (1991) Skin toxicity determined in vitro by three-dimensional, nativestate histoculture. Proc Natl Acad Sci USA. 88: 1908-1912.

36. Le Marois A (2013) Effect of ethanol on the Saccharomyces cerevisiae plasma membrane. Agro Paris Tech DA BioTech.

37. Cooper RA (1978) Influence of increased membrane cholesterol on membrane fluidity and cell function in human red blood cells. J Supramol Struct 8: 413-430.

38. Bastiaanse EM, Höld KM, Van der Laarse A (1997) The effect of membrane cholesterol content on ion transport processes in plasma membranes. Cardiovasc Res 33: 272-283.

39. Santanu B, Saubhik H (2000) Interactions between cholesterol and lipids in bilayer membranes. Role of lipid headgroup and hydrocarbon chain backbone linkage. Biochimica et Biophysica Acta 1467: 39-53. 